themselves and for the inhabitants of their countries. This is why you must consider the dissemination of the Geneva Conventions in your country as an obligation requiring your utmost efforts.

Just as it is true that a knowledge of a foreign language involves study of the grammar, work within the Red Cross can only be fully effective if based on adequate knowledge of the Geneva Conventions. "Knowledge is power" is an aphorism which has always been true. The Red Cross is a moral force, and its existence and authority should be defended first and foremost with the weapons of the spirit and the mind. That is what the great French poet Victor Hugo meant when he wrote to Henry Dunant: "You are arming humanity ".

\title{
Denmark
}

\section{The Red Cross and Refugees}

The United Nations High Commission for Refugees, on the occasion of the Red Cross Centenary, published an illustrated brochure entitled The Red Cross and Refugees, mention of which was made in the September 1963 issue of the International Review. We now learn that, following on the wish formulated by the U.N. High Commissioner for Refugees, recommending co-operation between the offices of the United Nations and the National Red Cross Societies on the local level, that is to say, in Denmark, the Information Centre for the Scandinavian countries and the Danish Red Cross, this brochure has recently been published in Danish by the Red Cross in Copenhagen, which ensures wide distribution among schools and the young. The publication represents a first tangible result of such co-operation which we have pleasure in pointing out to our readers. ${ }^{1}$

${ }^{1}$ Röde Kors og Flygtiningene, Dansk Röde Kors, Copenhagen, 1964. 
We would briefly recall that the brochure describes the action of the Red Cross on behalf of refugees in recent years, especially since 1939. It also, however, gives an account of the work accomplished by the ICRC on the eve of the First World War and which was at the origin of international aid to refugees. It was, moreover, on the initiative of the International Committee that a High Commissioner was appointed, charged with directing international aid for refugees. On February 20, 1921, Gustave Ador wrote to the President of the Council of the League of Nations :

... In begging you to be good enough to discuss at your present meeting the possible appointment of a League of Nations Commissioner for the Russian refugees, the International Committee is well aware that it is not so much a humanitarian duty which calls for the generous activities of the League of Nations as an obligation of international justice. The eight hundred thousand Russian refugees scattered throughout Europe are without legal protection or representation. All the organisations already at work would be glad to put forth fresh efforts under the general supervision of a Commissioner appointed by the League of Nations, which is the only supranational political authority capable of solving a problem which is beyond the power of exclusively humanitarian organisations...

This proposal was warmly received by a certain number of governments and since then the name of Nansen became a sort of symbol of international aid to refugees.

We congratulate the Danish Red Cross on the attractive presentation of the brochure and it is to be hoped that other National Societies follow suit.

\section{Great Britain}

\section{Distinction}

On December 9, 1964, at the British Red Cross Society's Council Meeting, Mr. Léopold Boissier, member of the ICRC and 